\title{
Posmononocoor
}

2017, vol. 77, 3-18

http://dx.doi.org/10.12657/denbio.077.001

\author{
Jan Esper, Adriana L. Carnelli, Christian Kamenik, Marc Filot, \\ Markus Leuenberger, Kerstin Treydte
}

\section{Spruce tree-ring proxy signals during cold and warm periods}

Received: 12 July 2016; Accepted: 26 October 2016

\begin{abstract}
The strength and temporal rigidity of climate signals are important characteristics of proxy data used to reconstruct climate variability over pre-instrumental periods. Here, we assess the performance of different tree-ring proxies, including ring width, maximum latewood density, $\delta^{13} \mathrm{C}$, and $\delta^{18} \mathrm{O}$, during exceptional cold (1800-1850) and warm periods (1946-2000). The analysis was conducted at a spruce (Picea abies) timberline site in the Swiss Alps in proximity to long homogenized instrumental records to support calibration tests against early temperature and precipitation data. In this cold environment, tree-ring width, maximum latewood density, and $\delta^{18} \mathrm{O}$ are mainly controlled by temperature variations. $\delta^{13} \mathrm{C}$ is influenced by various factors including temperature, precipitation, sunshine, and relative humidity. When comparing the response patterns during cold and warm periods, ring width and maximum latewood density revealed temporally stable temperature signals. In contrast, the association between the stable isotopes and climate changed considerably between the early 19th and late 20th centuries. The temperature signal in $\delta^{18} \mathrm{O}$ was stronger during the recent warm period, whereas the opposite is true for $\delta^{13} \mathrm{C}$. In $\delta^{13} \mathrm{C}$, the temperature signal weakened from the early 19 th to the late 20th centuries, but an (inverse) precipitation signal evolved indicating that soil moisture conditions additionally limited recent carbon isotope ratios. An attempt to combine the tree-ring proxies in a multiple regression model did not substantially improve the strength of the dominating temperature signal retained in the latewood density data as this proxy already explained a significant fraction of summer temperature variability. Our findings underscore the importance of split calibration/verification approaches including cold and warm periods, and challenge transfer models based on only late 20 th century observational data.
\end{abstract}

Keywords: stable isotopes, maximum latewood density, reconstruction model, Picea abies, Engadin, Alps

Addresses: J. Esper, Department of Geography, Johannes Gutenberg University, 55099 Mainz, Germany, e-mail: esper@uni-mainz.de

A.L. Carnelli, Laboratoire de Systèmes écologiques, École Polytechnique Fédéral de Lausanne,

1015 Lausanne, Switzerland

Ch. Kamenik, Institute of Geography, University of Bern, 3012 Bern, Switzerland

M. Filot, M. Leuenberger, Climate and Environmental Physics, University of Bern, 3212 Bern, Switzerland K. Treydte, Swiss Federal Research Institute WSL, 8903 Birmensdorf, Switzerland 


\section{Introduction}

Instrumental records provide valuable information on climate variability over the past 100-200 years (Böhm et al., 2001, 2010). To improve our understanding of pre-instrumental climate, reconstructions based on proxy data are needed (Frank et al., 2010; Jones et al., 2009). Among the most widespread proxies are tree-ring width (TRW) and maximum latewood density (MXD) chronologies used to reconstruct annually resolved temperature and hydroclimatic variations at regional (e.g., Büntgen et al., 2016; Cook et al., 2000; Davi et al., 2015; Esper et al., 2007, 2012; Gennaretti et al., 2014; Myglan et al., 2012), continental (e.g., Cook et al., 2015; Luterbacher et al., 2016), and hemispheric scales (e.g., D'Arrigo et al., 2006; Esper et al., 2002; Schneider et al., 2015; Wilson et al., 2016). However, the potential of trees to record additional climate elements including relative humidity, sunshine and cloud cover changes has not been fully explored, and the combination of widely used TRW and MXD chronologies with other tree-ring proxies such as stable isotope ratios, height increments and cell parameters might further improve climate reconstructions (e.g., Bräuning, 2001; Carrer et al., 2016; Fonti \& Babushkina, 2016; McCarroll et al., 2003). Only few studies have been conducted evaluating the climatic information recorded in both the classical tree-ring growth proxies, TRW and MXD, together with the stable isotope ratios, $\delta^{13} \mathrm{C}$ and $\delta^{18} \mathrm{O}$ (e.g., Esper et al., 2015a; Gagen et al., 2006; Hartl-Meier et al., 2015; Kirdyanov et al., 2008; Treydte et al., 2001).

Tree-ring $\delta^{13} \mathrm{C}$ and $\delta^{18} \mathrm{O}$ are controlled by climate through effects on stomatal conductance, photosynthetic rates and source water isotopic signatures (Leavitt, 2010). Other environmental factors such as air pollution or thinning might disturb the link between isotopes and climate (e.g., Saurer et al., 1995; Warren et al., 2001). Meanwhile several isotope/climate calibration studies have been completed (overview in Frank et al., 2015; Treydte et al., 2007), but only few focus on high elevation sites where the classical TRW and MXD growth proxies are known to contain significant temperature signals (e.g., Gagen et al., 2006; Konter et al., 2014; Kress et al., 2010; Treydte et al., 2001, 2006). Disentangling climate signals from species and site specific responses, based on observational data, remains a major challenge in high resolutions paleoclimatology (Rebetez et al., 2003; Treydte et al., 2007, 2009), and compared to the classical tree-ring proxies, little is known about the coherence of stable isotopes with pre-20th century climate data. The majority of isotope-calibration studies focus on the last 100 years (e.g., Hemming et al., 1998; McCarroll \& Pawellek, 2001; Saurer et al., 2014; Treydte et al., 2007), and only few include the late 19th century or even longer periods (e.g., Masson-Delmotte et al., 2005; Saurer et al., 2000).

In this paper, we contribute to this issue and analyze the dependency of TRW, MXD, $\delta^{13} \mathrm{C}$ and $\delta^{18} \mathrm{O}$ on climate during an early 19th century cold and a late 20 th century warm calibration period. The early calibration period (AD 1800-1850) includes the termination of the Little Ice Age characterized by cold conditions at regional (Büntgen et al., 2006) to hemispheric scales (Schneider et al., 2015). According to long instrumental data, annual temperatures were substantially colder $\left(\sim 0.6^{\circ} \mathrm{C}\right)$ compared to the second half of the 20th century (Casty et al., 2005). The early calibration period includes some of the coldest Alpine summers of the past 500 years, including the 1816 'year without a summer' forced by a major volcanic eruption in the tropics (Esper et al., 2013) and a period of low solar activity (Dalton Minimum) until the late 1820s (Luterbacher et al., 2004, 2016). The 1840s were characterized by high annual precipitation sums (Casty et al., 2005).

In contrast, the recent calibration period (AD 1946-2000) is characterized by overall warmer conditions, likely including some of the warmest summers of the past millennium (Luterbacher et al., 2016). Summers were particularly warm from 19461950 and from 1970-2000, with the latter period accompanied by a decrease in precipitation (Casty et al., 2005). We here consider these two similarly long, cold and warm periods, to (i) assess the climatic signals recorded in TRW, MXD, $\delta^{13} \mathrm{C}$ and $\delta^{18} \mathrm{O}$, (ii) evaluate the temporal changes in signal strength from the early 19 th to the late 20th centuries, and (iii) test the effects of combining tree-ring proxies to improve reconstruction skill. The study is conducted at a high elevation Picea abies site in the Swiss Engadin in the vicinity of long instrumental temperature and precipitation data covering the past $200+$ years. In addition, we consider sunshine hour and relative air humidity data over the recent calibration period to compare climate signals over the late 20 th century.

\section{Data and Methods}

\section{Tree-ring proxies}

The tree-ring sampling site is located in the Upper Engadin in the Swiss Alps at the northern slope of Piz Mezzaun in proximity to the Albula Pass (Fig. 1). The Engadin is situated in the rain shadow of surrounding mountain ranges and is classified as an "inner-alpine dry valley”. Mild summers, cold winters, low humidity and above-average sunshine characterize the local climate. Mean annual and summer temperatures recorded at the nearby station in Sils Maria (1961-1990) are $1.8^{\circ} \mathrm{C}$ and $10.5^{\circ} \mathrm{C}$, respectively. 

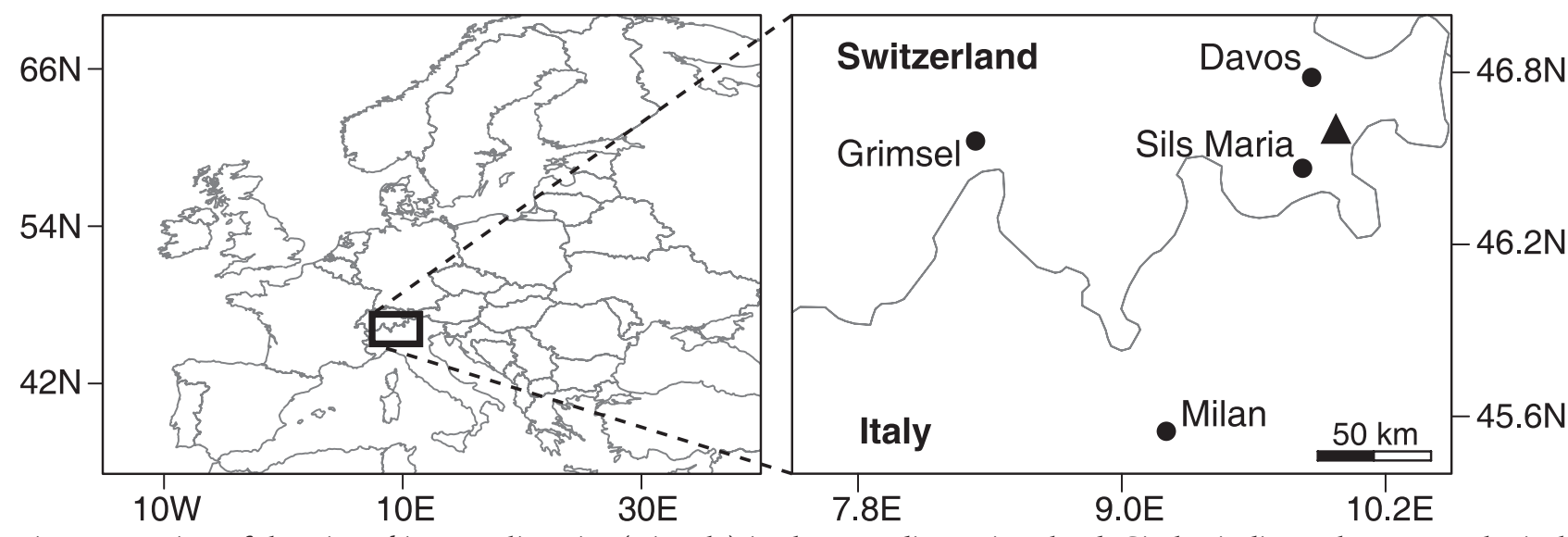

Fig. 1. Location of the Picea abies sampling site (triangle) in the Engadin, Switzerland. Circles indicate the meteorological stations in Davos $\left(46.80^{\circ} \mathrm{N}, 9.82^{\circ} \mathrm{E}\right)$, Sils Maria $\left(46.42^{\circ} \mathrm{N}, 9.76^{\circ} \mathrm{E}\right)$, and Milan $\left(45.47^{\circ} \mathrm{N}, 9.17^{\circ} \mathrm{E}\right)$, as well as the GNIP station in Grimsel $\left(46.56^{\circ} \mathrm{N}, 8.34^{\circ} \mathrm{E}\right)$

Annual precipitation equals $980 \mathrm{~mm}$ and includes a minor summer maximum of $335 \mathrm{~mm}$. Precipitation primarily originates from west- to south-westerly air masses entering over the Maloja Pass.

Two core samples from 36 spruce trees of different age classes were collected (Table 1). The trees are situated in $1900 \mathrm{~m}$ a.s.l. near the species' distribution limit on well drained soils from acidic bedrock (gneiss) on a $40 \%$ inclined slope. The plant community consists of an unmanaged, open ( $40 \%$ tree cover) conifer forest including Larix decidua, Pinus cembra and Picea abies. Forest understory is dominated by Vaccinium myrtillus, Rhododendron ferrugineum and Calamagrostis villosa. Herb layer coverage is $\sim 80 \%$, shrub coverage is $\sim 10 \%$.

We measured TRW on the 72 core samples using the TSAP software (Rinn, 2003) and crossdated the series visually and using the software COFECHA (Holmes, 2000). Fourteen of the older $(\sim 250$ years) trees were selected for MXD measurement following standard X-ray densitometry procedures (Schweingruber et al., 1978). Among these, another four trees, from which two additional core samples were collected, were selected for isotope analysis. We used the latewood of these samples for stable isotope measurements to avoid carry-over effects of carbohydrate reserves, and discarded the innermost 30 rings of each tree to avoid potentially biasing effects due to juvenile discrimination trends (Leavitt, 2010; but see also Esper et al., 2010; Helama et al., 2015). The latewood samples were pooled using a Retsch mill (Leavitt \& Long, 1984; Treydte et al., 2001) and cellulose extracted following standard procedures (Brenninkmeijer, 1983; McCarroll \& Loader, 2004). Samples were combusted to $\mathrm{CO}_{2}$ for carbon isotope measurement and pyrolized to CO for oxygen isotope measurement using an elemental analyzer coupled to a mass spectrometer. In some years, insufficient cellulose was extracted, causing gaps in the $\delta^{13} \mathrm{C}$ (1809, $1825,1845,1966,1974,1982)$ and $\delta^{18} \mathrm{O}$ chronologies $(1800,1840,1966,1974,1992)$.

All isotopic values are given in $\delta$-notation relative to a standard in per mill $\left[\delta=\left(\mathrm{R}_{\text {sample }} / \mathrm{R}_{\text {standard }}-1\right) \cdot 1000\right]$ (Leavitt, 2010). $\delta^{13} \mathrm{C}$ is the ratio of ${ }^{13} \mathrm{C}$ to ${ }^{12} \mathrm{C}$ from the combustion of pooled latewood samples and a reference fossil belemnite from the Pee Dee Formation of the upper Cretaceous in South Carolina. $\delta^{18} \mathrm{O}$ is the ratio of ${ }^{18} \mathrm{O}$ to ${ }^{16} \mathrm{O}$ from latewood samples relative to

Table 1. Tree-ring proxy summary statistics for the 1800-1850 and 1946-2000 periods. TRW and MXD data are 300-year spline detrended, $\delta^{13} \mathrm{C}$ corrected for changes in the atmosphere due to fossil fuel combustion

\begin{tabular}{lcccc}
\hline & TRW & MXD & $\delta^{13} \mathrm{C}$ & $\delta^{180}$ \\
\hline No. of trees & 36 & 14 & 4 & 4 \\
No. of cores & 72 & 29 & 8 & 8 \\
1800-1850 & & & & 48 \\
No. of years used in correlation & 51 & 51 & - & - \\
Inter-series correlation & 0.28 & 0.44 & - & - \\
EPS & 0.93 & 0.93 & 51 & 51 \\
1946-2000 & & & - \\
No. of years used in correlation & 55 & 55 & - & - \\
Inter-series correlation & 0.32 & 0.42 & - & - \\
EPS & 0.96 & 0.95 & & - \\
\hline
\end{tabular}


standard mean ocean water. Measurement accuracy was estimated considering the standard deviation from commercial cellulose at $\pm 0.2 \%$ or carbon and $\pm 0.15 \%$ o for oxygen isotope ratios. We measured latewood cellulose $\delta^{13} \mathrm{C}$ and $\delta^{18} \mathrm{O}$ over the periods 1800-1850 and 1946-2000.
The TRW and MXD measurement series were standardized by power transforming the data (Cook \& Peters, 1997) and calculating residuals from 300year fixed splines (Fig. 2). Inter-series correlations were slightly lower among the detrended TRW series $(\mathrm{r}=0.28$ and 0.32 over the early and late calibration periods) compared to MXD $(r=0.44$ and 0.42$)$.

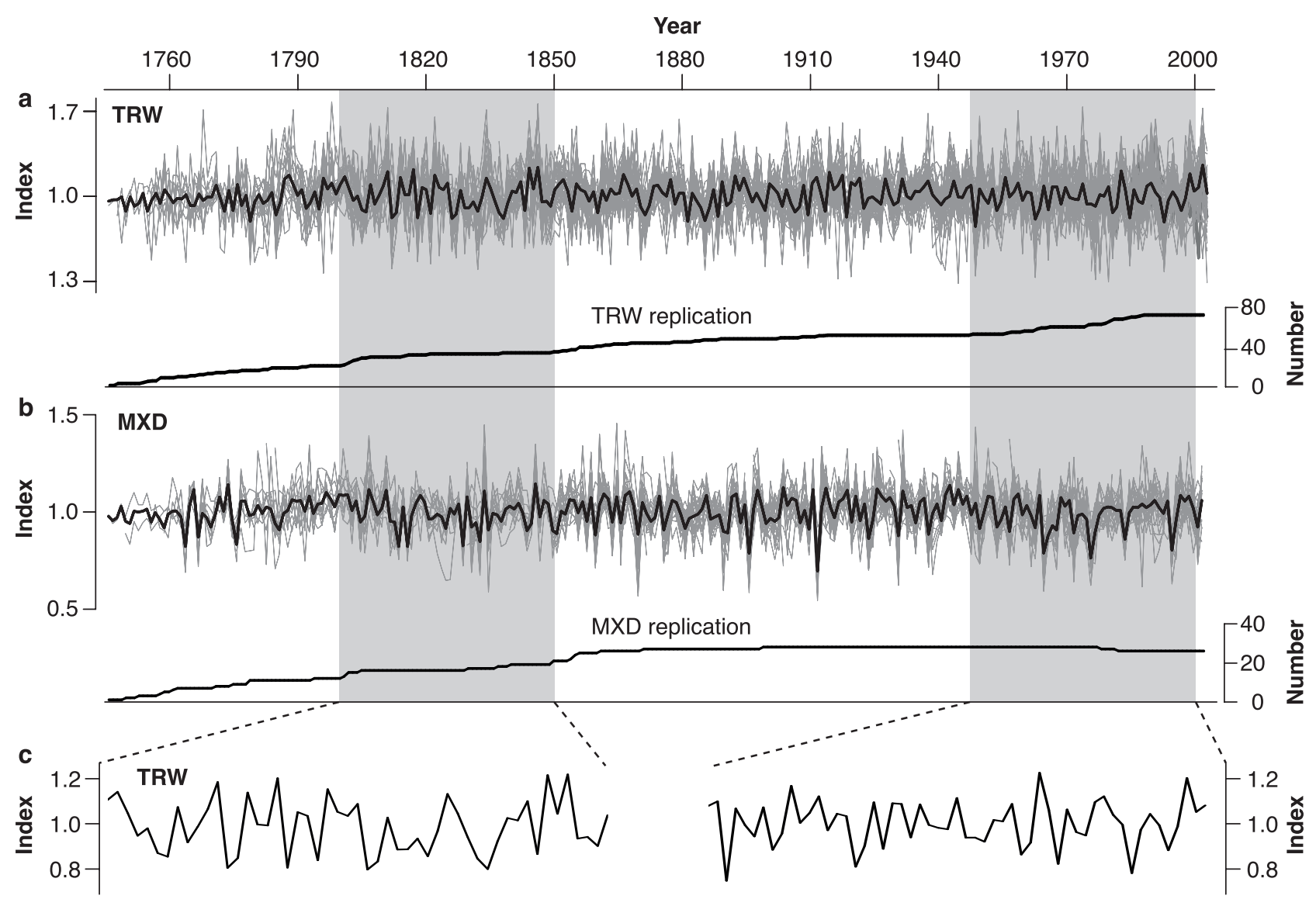

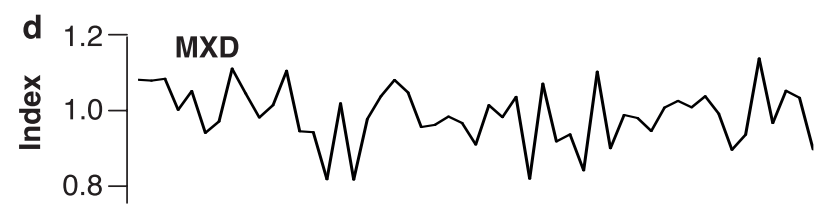

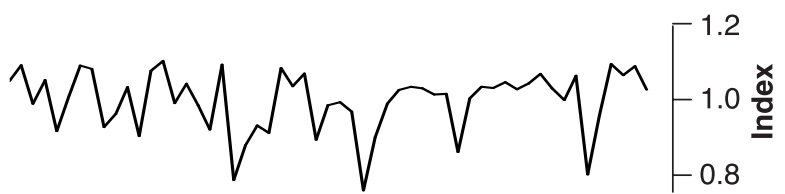

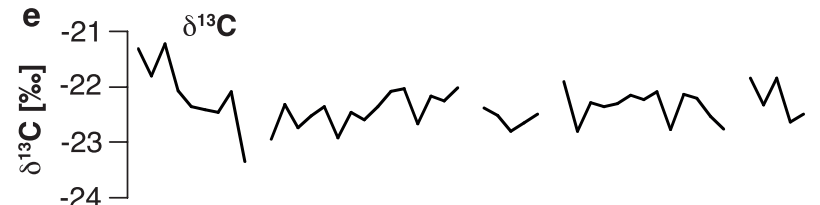

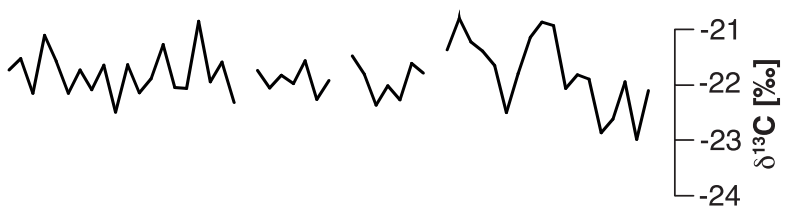
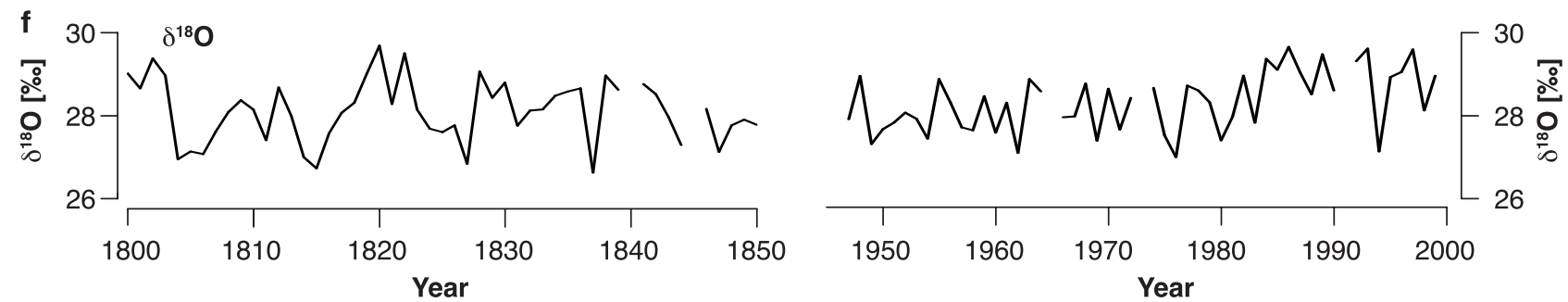

Fig. 2. Tree-ring proxies. a, Picea abies TRW series after removing age trend using 300 -year splines. Black curve is the biweight robust mean chronology. Bottom panel shows the temporally changing sample replication. $\mathbf{b}$, Same as in $\mathbf{a}$, but for MXD. Panels c-f show the TRW, MXD, $\delta^{13} \mathrm{C}$, and $\delta^{8} \mathrm{O}$ chronologies over the 1800-1850 and 1946-2000 periods. Gaps in the $\delta^{13} \mathrm{C}$ and $\delta^{18} \mathrm{O}$ chronologies result from insufficient latewood cellulose extraction 
However, calculation of the expressed population signal (EPS; Wigley et al., 1984) revealed that both proxies exceed the widely recognized EPS $=0.85$ threshold used to identify periods over which treering proxy records retain meaningful information on past climate variability (Table 1 ). Mean chronologies of the detrended TRW and MXD series were used for comparison with the stable isotope series and instrumental data. For $\delta^{13} \mathrm{C}$, we corrected these data for changes in the atmospheric $\mathrm{CO}_{2}$ isotope ratio attributable to fossil fuel combustion (Francey et al., 1999) to avoid spurious correlations due to artificial long-term trends (Treydte et al., 2009).

\section{Observational data and calibration}

For proxy calibration, we used the long temperature station record from Milan $\left(r_{1946-2000}=0.82\right.$ with the shorter Sils Maria summer temperature record) $\sim 120 \mathrm{~km}$ southwest of the tree-ring sampling site (Böhm et al., 2001), and the long precipitation record from the nearest grid point of a $0.5^{\circ} \times 0.5^{\circ}$ network (see Casty et al., 2005 for covariance assessments). In addition to these long records, we used sunshine hour and relative humidity data from the nearby Davos climate station (1590 m a.s.l.) for calibration over the $1946-2000$ period, as well as $\delta^{18} \mathrm{O}$ in precipitation from the GNIP (Global Network of Isotopes in Precipitation) station in Grimsel (1950 m a.s.l.) over the 1971-1992 period.

Climate correlations were calculated using the (i) original, and (ii) high-pass filtered tree-ring proxy and instrumental data over the early 1800-1850 (only temperature and precipitation) and late 19462000 calibration periods (1971-1992 for precipitation $\delta^{18} \mathrm{O}$ ). "Original" data refers to the 300 -year spline detrended TRW and MXD chronologies, the corrected $\delta^{13} \mathrm{C}$ chronology, and the untreated $\delta^{18} \mathrm{O}$ chronology, as well as the monthly and seasonal climate data. For assessments in the high frequency domain, all proxy and instrumental data were high-pass filtered by calculating residuals from a 5-year Kernel filter (Gasser \& Müller, 1984). Significance estimates were adjusted for changing degrees of freedom due to varying serial correlations (Trenberth, 1984).
To facilitate the development of a reconstruction model based on multiple predictors, we first tested the climate sensitivity of TRW, MXD, $\delta^{13} \mathrm{C}$ and $\delta^{18} \mathrm{O}$ simultaneously using Redundancy Analysis (RDA), a non-symmetric method summarizing the redundant variance among tree-ring parameters explained by the climate variables (van den Wollenberg, 1977). We ran a series of RDAs using standardized climate variables and estimate significance based on 1000 re-samplings within a Monte Carlo approach (ter Braak \& Smilauer, 2002). We then established transfer functions for the significant climate variables explaining most of the tree-ring proxies' variance. Ordinary least-squares and partial least squares regressions are tested (Hastie et al., 2001) using the PLS and CAR R-packages (Fox, 2002; R Core Team, 2014), and predictors retained leading to a $>5 \%$ reduction of the root mean squared error (RMSE) (Birks, 1995). Using leave-one-out validation, a technique based on subsampling and rebuilding models using $\mathrm{n}-1$ data, we selected a 'minimal adequate model' (Crawley, 1993) reaching the highest coefficient of determination $\left(\mathrm{R}^{2}\right)$ and lowest RMSE.

\section{Results}

\section{Inter-proxy correlations}

Cross-correlations among the four tree-ring proxies over the early and late calibration periods ranged from $r_{1946-2000}=-0.20\left(\mathrm{TRW}-\delta^{13} \mathrm{C}\right)$ to $\mathrm{r}_{1946-2000}=0.41$ $\left(\mathrm{MXD}-\delta^{18} \mathrm{O}\right.$; Table 2$)$. The latter correlation even increased to $r=0.49$ if the high-pass filtered data were considered (values in parenthesis in Table 2). The correlation values changed considerably between the early and late calibration periods, except perhaps for TRW versus MXD. Most notably, the correlation between $\delta^{13} \mathrm{C}$ and MXD shifted from $\mathrm{r}_{1800-1850}=0.36$ to $r_{1946-2000}=0.08$ indicating a complete loss of common variance from the early cold to the late warm period. Low correlations between TRW and stable isotopes are partly explained by the sampling scheme, as TRW is typically dominated by earlywood whereas the isotopes ratios were obtained from latewood produced

Table 2. Correlation coefficients among tree-ring proxies over early (1800-1850) and late (1946-2000) calibration periods. Values in parentheses are calculated using 5-year high-pass filtered chronologies. Bold values are significant at $\mathrm{p}<0.05$, underlined values at $\mathrm{p}<0.01$

\begin{tabular}{lcccc}
\hline & & MXD & $\delta^{13} \mathrm{C}$ & $\delta^{18} \mathrm{O}$ \\
\hline $1800-1850$ & TRW & $0.20(0.20)$ & $0.21(0.23)$ & $0.12(0.05)$ \\
& MXD & - & $0.36(0.22)$ & $0.25(0.03)$ \\
& $\delta^{13} \mathrm{C}$ & - & - & $0.33(0.20)$ \\
\hline $1946-2000$ & TRW & $0.29(0.35)$ & $-0.20(-0.02)$ & $0.20(0.14)$ \\
& MXD & - & $0.08(0.11)$ & $0.41(0.49)$ \\
& $\delta^{13} \mathrm{C}$ & - & - & $0.06(0.23)$ \\
\hline
\end{tabular}


later in the season during high and late summer. While the correlation between $\delta^{13} \mathrm{C}$ and $\delta^{18} \mathrm{O}$ also changed notably from $r_{1800-1850}=0.33$ to $r_{1946-2000}=$ 0.06 , the association between stable isotope chronologies remained fairly stable when considering highpass filtered data $(0.20$ and 0.23$)$.

\section{TRW and MXD climate response}

Both TRW and MXD are characterized by a dominating warm season temperature signal (Fig. 3). The signal is substantially stronger in MXD, though in both growth proxies it is temporally stable, i.e. similar between the early and late calibration periods. In TRW, the signal is stronger in the high-pass filtered data.

The TRW chronology correlated positively with May-July temperatures $\left(\mathrm{r}_{1800-1850}=0.33, \mathrm{r}_{1946-2000}=\right.$ 0.34 ) reaching maximum values in the high-pass filtered data with June-July temperatures $\left(\mathrm{r}_{1800-1850}=\right.$ 0.56, $\mathrm{r}_{1946-2000}=0.53$; Table 3 and Fig. 4). Besides temperature, other climate parameters affected TRW including March-April precipitation during the early cold period $\left(\mathrm{r}_{1800-1850}=-0.33\right)$, as well as May relative humidity $\left(\mathrm{r}_{1946-2000}=-0.30\right)$ and May sunshine $\left(\mathrm{r}_{1946-}\right.$ $\left.{ }_{2000}=0.30\right)$ during the late warm period. Note that humidity and sunshine are also inter-related (e.g., $r$ $=-0.49$ during May).

The MXD chronology correlated best with July-September temperatures $\left(r_{1800-1850}=0.64, r_{1946-2000}\right.$ $=0.62$, Fig. 4). Recent sunshine and relative humidity data also correlated significantly, but overall were of lesser importance to cell wall growth $(\mathrm{r}=0.48$ and -0.48 , respectively). During the recent period, an additional July-September moisture signal is retained $\left(r_{1946-2000}=-0.30\right)$. This response is likely related to the increased co-variance between temperature and precipitation typically exceeding $r=-0.30$ during the summer months in the European Alps (Casty et al., 2005).

\section{$\delta^{13} \mathrm{C}$ climate response}

The $\delta^{13} \mathrm{C}$ chronology correlated significantly with multiple climate parameters, ranging from $r=-0.30$ to $\mathrm{r}=0.56$, including a temporal strengthening of the precipitation signal (Fig. 3). July-August is the most important season for carbon isotope fractionation with the closest relationship recorded with recent sunshine hour data $\left(r_{1946-2000}=0.56\right)$. Temperature and precipitation also influenced $\delta^{13} \mathrm{C}$, but their relevance changed between the two calibration periods. Whereas temperature appeared to be the dominating forcing during the early period $\left(\mathrm{r}_{1800-1850}\right.$ $=0.49)$, its impact is reduced in the recent period $\left(r_{1946-2000}=0.29\right)$. A reversed tendency was revealed for precipitation, with coefficients being more negative in the recent $\left(r_{1946-2000}=-0.44\right.$, June-August) compared to the early period $\left(\mathrm{r}_{1800-1850}=-0.27\right)$. These changes indicate $\delta^{13} \mathrm{C}$ sensitivity to temperature was enhanced in cooler conditions, whereas in the warmer late 20th century the proxy more closely reflected plant water status. The relationships found for $\delta^{13} \mathrm{C}$ did not vary markedly in the higher

Table 3. Most significant correlations between tree-ring proxies and climate data over the early (1800-1850) and late (1946-2000) calibration periods. Sunshine and relative humidity data available over only the late period. Bold values are significant at $\mathrm{p}<0.01$, regular values at $\mathrm{p}<0.05$, values in parenthesis are insignificant. Asterisks indicate cases where maximum correlations were reached between high-pass filtered chronologies

\begin{tabular}{|c|c|c|c|c|}
\hline Proxy & Parameter & Season & $1800-1850$ & 1946-2000 \\
\hline \multirow[t]{4}{*}{ TRW } & Temperature & Jun-Jul & $0.56^{*}$ & $0.53^{*}$ \\
\hline & Precipitation & Mar-May & -0.33 & -0.06 \\
\hline & Sunshine & Jun-Jul & - & $0.35^{*}$ \\
\hline & Rel. humidity & May & - & -0.30 \\
\hline \multirow[t]{4}{*}{ MXD } & Temperature & Jul-Sep & 0.64 & 0.62 \\
\hline & Precipitation & Jul-Sep & $(-0.02)$ & -0.30 \\
\hline & Sunshine & Jul-Sep & - & 0.48 \\
\hline & Rel. humidity & Jul-Sep & - & -0.48 \\
\hline \multirow[t]{4}{*}{$\delta 13 \mathrm{C}$} & Temperature & Jul-Aug & 0.43 & 0.28 \\
\hline & Precipitation & Jun-Aug & -0.27 & -0.44 \\
\hline & Sunshine & Jul-Aug & - & 0.56 \\
\hline & Rel. humidity & Jul-Aug & - & -0.45 \\
\hline \multirow[t]{4}{*}{$\delta 180$} & Temperature & Aug & 0.28 & 0.46 \\
\hline & Precipitation & Aug & -0.35 & -0.04 \\
\hline & Sunshine & Jul-Sep & - & $0.39 *$ \\
\hline & Rel. humidity & Jul-Aug & - & $-0.52^{*}$ \\
\hline
\end{tabular}




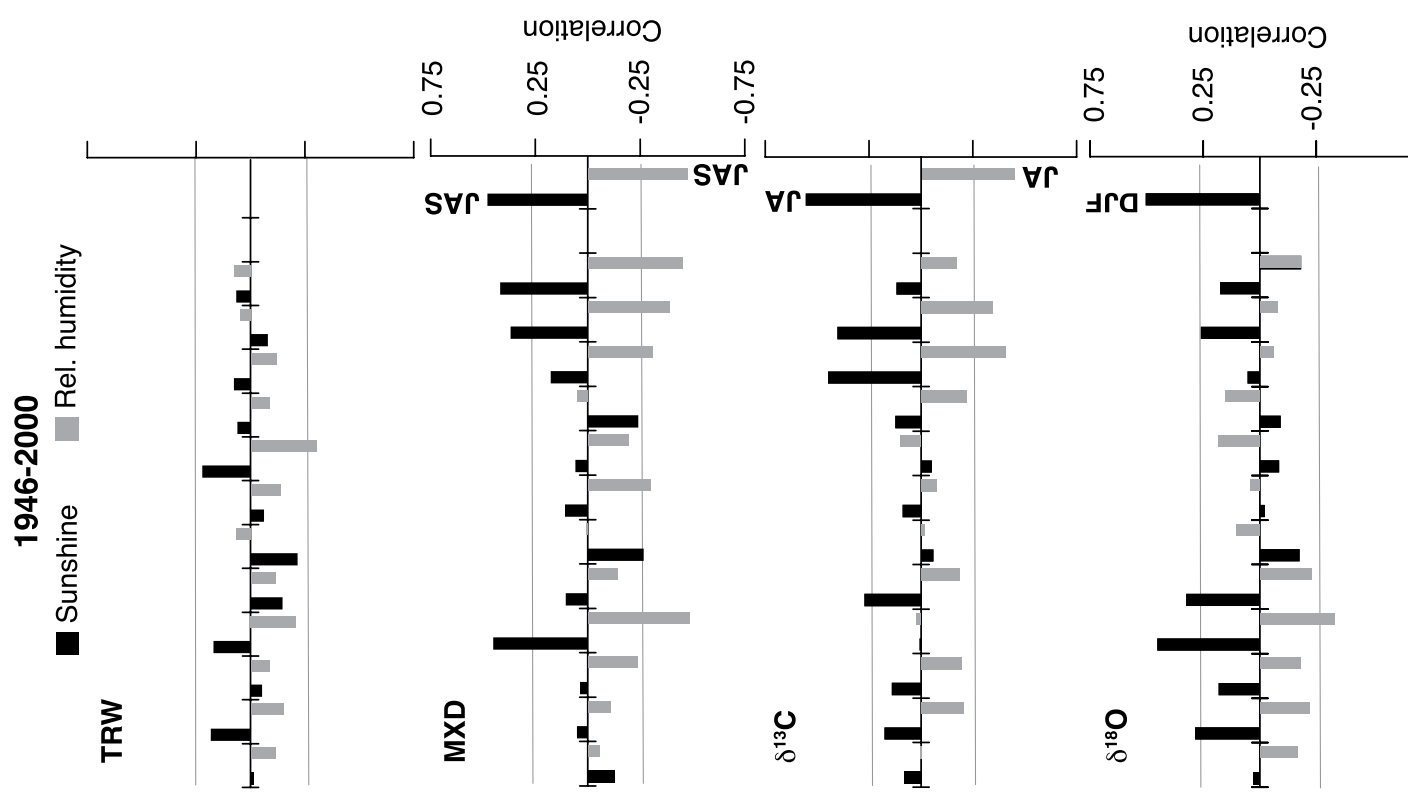

它

i. ฐं

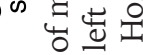
の ธี ซี $\varangle$ ت. $\checkmark$ 今

$\supset$ 잉 융

$\sum$ 인

$\varangle$ क्ष

$\Sigma$ 击

$4 \quad \overrightarrow{0}$.

$>$ हृ

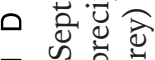

$z$ 逐

$\circ$ 苛

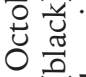
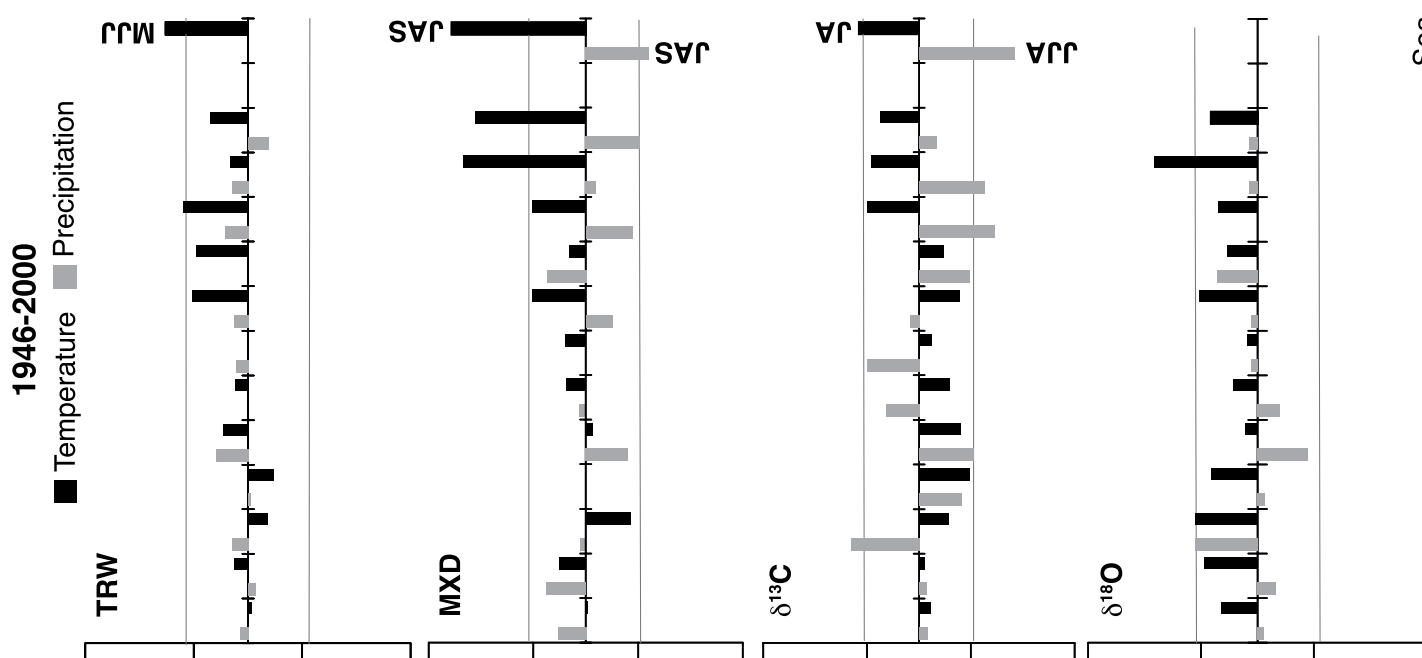

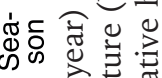

$\infty 0$

$\varangle$ है छ

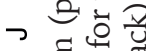

$\neg$ 要

$\Sigma \pi$ क

$<$ 형

$\Sigma$ चु

4.0

웡

० 0 ते

- 包同寻

$z$

0 至 $\mathrm{v}$

我尔

घี चु

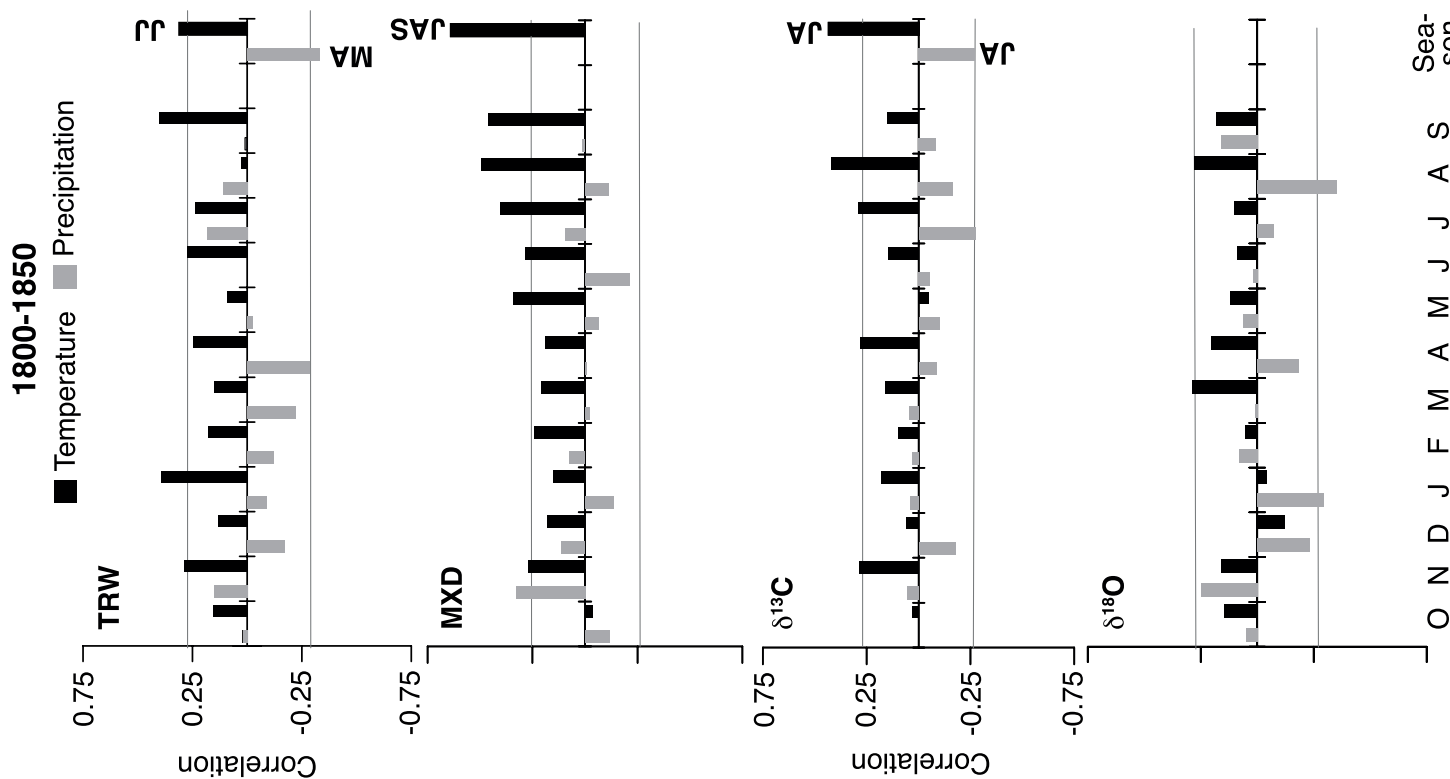

ळi

ส

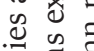

の

$\varangle \quad$

(5) 8 .

$\supset$ त

$\Sigma$ ปี

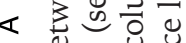

$\Sigma$ ป ป

- 두유

,

च ठै

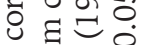

กี

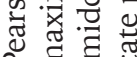

¿ छ छ

ก.

ио!ฺе|әגоว

ио!̣е|әגој 
frequency domain, except for the temperature response being stronger in the recent calibration period $\left(r_{1946-2000}=0.39\right)$.

\section{$\delta^{18} \mathrm{O}$ climate response}

The latewood $\delta^{18} \mathrm{O}$ data contained a significant late summer temperature signal, but this signal was weaker during the early calibration period $\left(\mathrm{r}_{1800-1850}=\right.$ $0.28)$ compared to the late 20th century $\left(\mathrm{r}_{1946-2000}=\right.$ 0.46 , Fig. 4). The temperature signal was also weaker when considering high-pass filtered data, where relative humidity and sunshine appeared to the main drivers of recent inter-annual $\delta^{18} \mathrm{O}$ variations (Table $3)$. However, the $\delta^{18} \mathrm{O}$ temperature signal is additionally supported by a comparison with the GNIP station
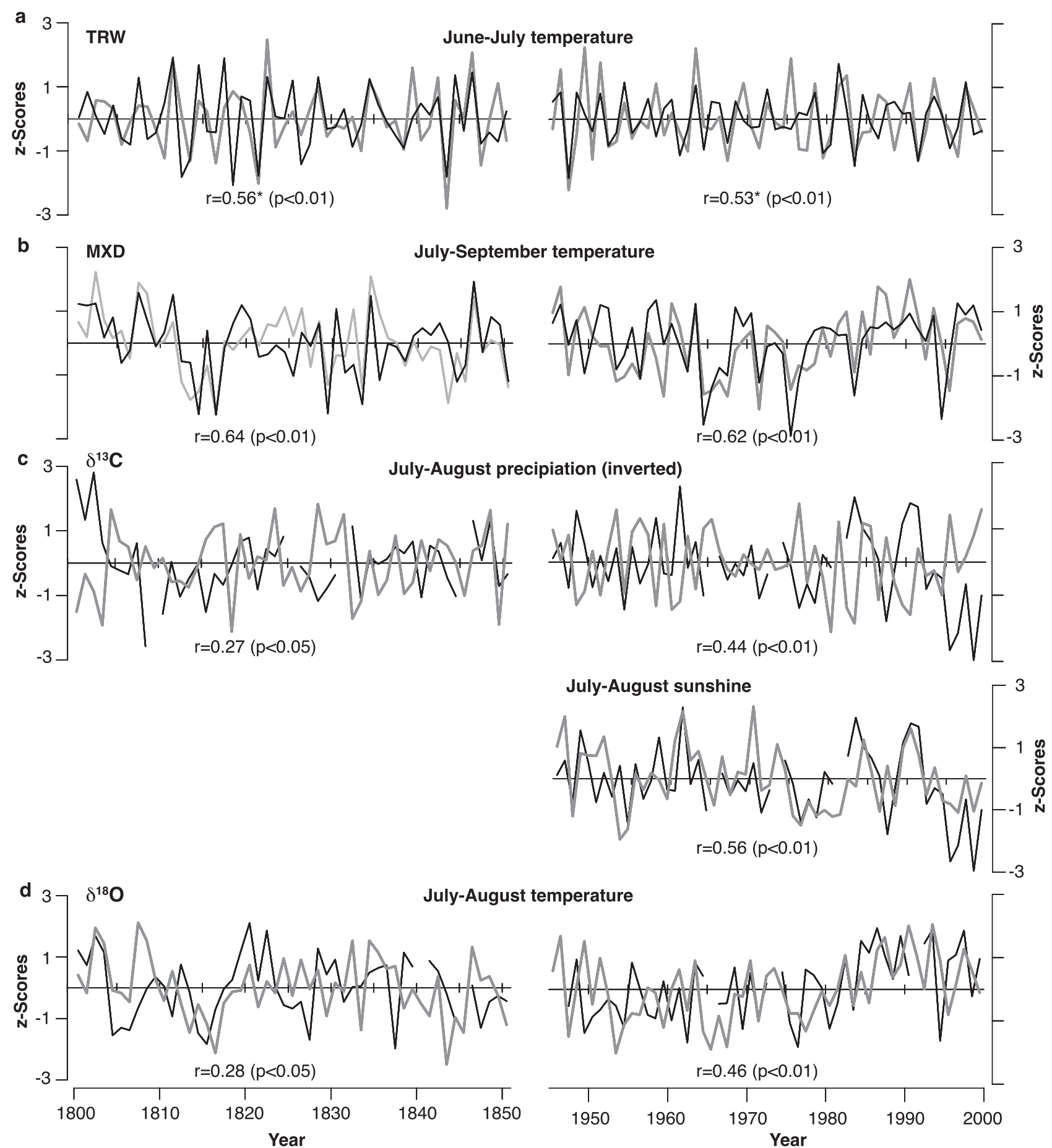

Fig. 4. Tree-ring proxies (black) shown together with the best correlating climate variables (grey) over the 1800-1850 and 1946-2000 calibration periods. Sunshine hour data were only available over the late calibration period (panel c). TRW and June-September temperature data were 5-year high-pass filtered (panel a). All records are scaled to zero mean and unit variance 


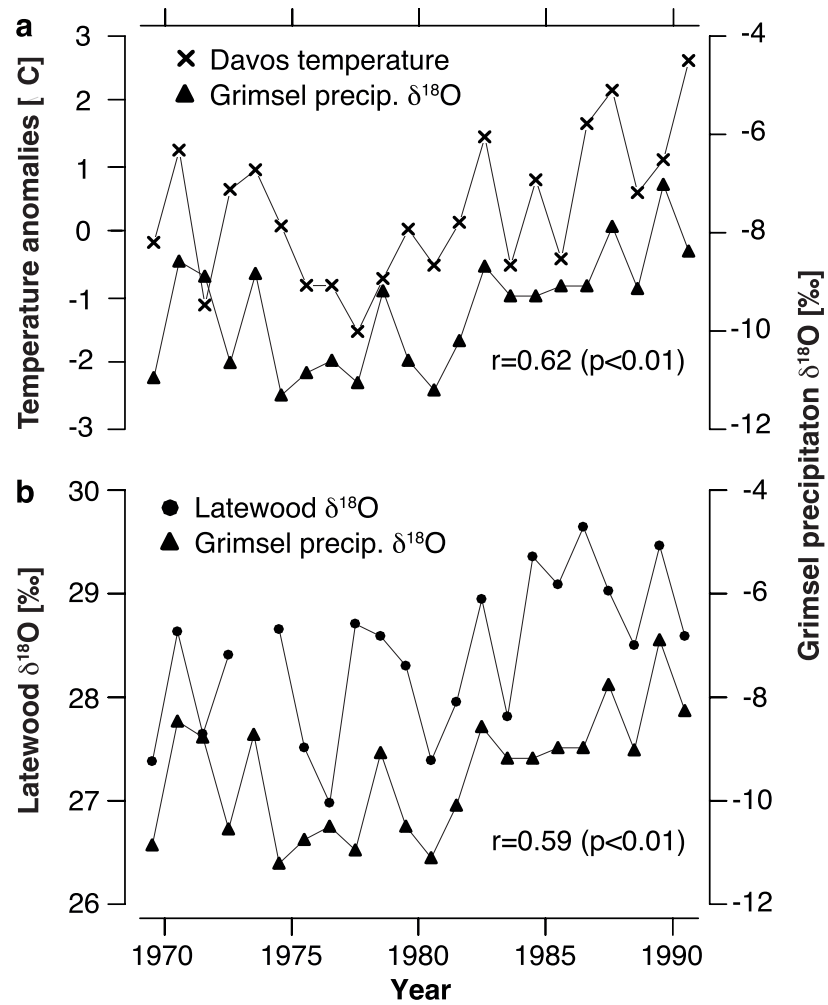

Fig. 5. July-August $\delta^{18} \mathrm{O}$ in precipitation recorded at the Grimsel GNIP station plotted together with a, July-August temperatures from Davos, and $\mathbf{b}, \delta^{18} \mathrm{O}$ in Picea abies tree-rings from the Engadin over the 1970-1991 period

in Grimsel. Highest correlations were obtained with $\delta^{18} \mathrm{O}$ recorded in late summer rainfall $(r=0.59$, Fig. $5)$. This finding is in line with similar investigations from Central Switzerland (Saurer et al., 1997, 2000) and supports water uptake as the main pathway controlling tree-ring $\delta^{18} \mathrm{O}$. The tree-ring $\delta^{18} \mathrm{O}$ chronology contains a decadal scale increase in the late 20th century that is also reflected in the GNIP stable isotope and Davos temperature records (Fig. 5a). A precipitation signal is largely absent in $\delta^{18} \mathrm{O}$.

\section{Combining tree-ring proxies}

Using RDA we found that May-September temperatures explained most variance of the combined treering dataset over the recent 1946-2000 calibration period $(15.9 \%, \mathrm{p}<0.05)$. July-September sunshine hours explained $12.6 \%$, July-September relative humidity $9.5 \%$, and previous year June-March precipitation $7.7 \%$. During 1800-1850, March-November temperature accounted for $24.5 \%$ and May-July precipitation for $13.4 \%$ of the combined proxy variance. As temperature explained most variance, we joined the early and late calibration period data. In this approach, RDA revealed July-September temperature to account for the largest fraction of proxy variance (16.8\%) including $18.7 \%$ during $1800-1850$ and $15.8 \%$ during $1946-2000$ periods. Considering this season, we developed a proxy-based temperature model using multiple ordinary least-squares regression explaining $46 \%$ of July-September instrumental temperature variability $(44.3 \%$ using partial leastsquares regression, RMSE $\left.=0.75-0.77^{\circ} \mathrm{C}\right)$. According to type-II variance analysis (Fox, 2002), only MXD and $\delta^{13} \mathrm{C}$ significantly explained July-September temperature variability in this regression model (Fig. 6).

\section{Discussion}

Our analysis shows that TRW, MXD, $\delta^{13} \mathrm{C}$ and $\delta^{18} \mathrm{O}$ contain relevant information on the variability of several meteorological parameters. TRW is mainly influenced by temperature fluctuations in the early to mid growing season (May-July), whereas high and late summer conditions (July-September) impact MXD and the tree-ring stable isotopes. We here focus on the changing climatic controls of the four climate proxies during the early and late calibration periods.

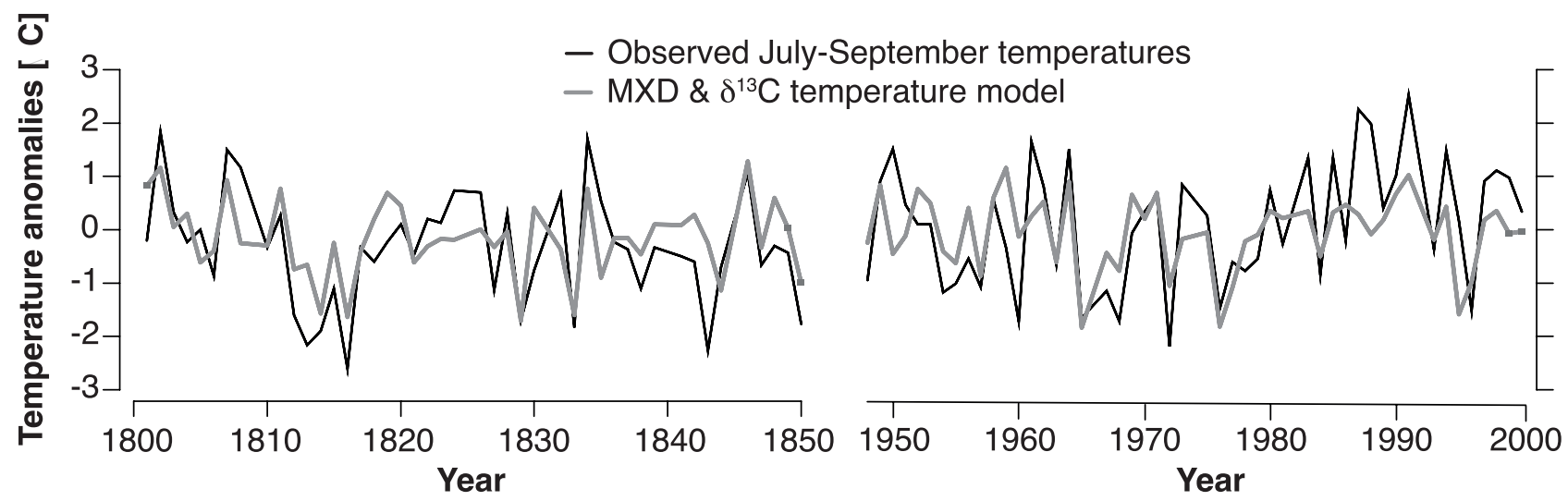

Fig. 6. Modeled (grey) and observed (black) July-September temperatures over the 1800-1850 and 1946-2000 periods. The model is derived from ordinary least-squares regression including MXD and $\delta^{13} \mathrm{C}$ as predictors 


\section{Temperature and sunshine}

In the high elevation Picea abies site considered here, TRW and MXD are primarily controlled by temperature displaying temporally stable relationships. The temperature signal derives from the fact that these proxies are integrative products of the trees' photosynthesis that, in turn, is directly regulated by air temperature and irradiance in high elevation sites (Frank \& Esper, 2005). TRW and MXD exhibit differing sensitivities to varying frequencies of temperature change. Higher frequency temperature fluctuations from late spring to early summer are most significant to TRW. It is well established that temperature variations in the early growing season regulate cell division and enlargement (Tranquillini, 1979), and that higher temperatures stimulate cambial activity resulting in wider rings (Kirdyanov et al., 2003). This connection is even tighter for the proxy reflecting cell wall thickening (MXD) in thermally limited environments (Briffa et al., 1998; Esper et al., 2012, 2015b; Frank \& Esper, 2005; Schneider et al., 2015). In contrast to TRW, MXD showed the highest sensitivity using the original (not high-pass filtered) data. Anatomical studies revealed MXD variability is better explained by changes in growing season length than changes in seasonal mean temperatures (Moser et al., 2010; Kirdyanov et al., 2003). Higher summer temperatures promote the synthesis of cell wall components, but limit the duration of tracheid development, resulting in relatively minor net effects on xylem densities (Antonova \& Stasova, 1997).

Our analysis indicates tree-ring $\delta^{13} \mathrm{C}$ and $\delta^{18} \mathrm{O}$ to be influenced by temperature as well. Yet in comparison to TRW and MXD, the strength of temperature control varies considerably between early 19th and late 20th centuries. Stable isotope ratios are regulated by temperature via processes that differ fundamentally from the tree-ring growth proxies. The oxygen isotope ratio retained in latewood cellulose combines the isotopic signature of the source water with the signature from evaporative enrichment of leaf water regulated by the plant's transpiration demand (Dongmann et al., 1974). The significant correlations between rainfall and tree-ring cellulose oxygen isotopes reported here demonstrate that, at our high elevation site, latewood $\delta^{18} \mathrm{O}$ is mainly recording the isotopic composition of precipitation during the growing season, and can thus be considered as a proxy of condensation temperature. Similar associations have been reported for spruce (Anderson et al., 1998; Jäggi et al., 2003) and other species from central European sites (Raffalli-Delerce et al., 2004; Saurer et al., 2000). Using diurnally resolved data, maximum daytime air temperatures during the growing season were shown to be the key driver of $\delta^{18} \mathrm{O}$ in fir trees from Central Switzerland (Rebetez et al., 2003). While the temperature sensitivity of $\delta^{18} \mathrm{O}$ is slightly more consistent compared to $\delta^{13} \mathrm{C}$, the signal is still much tighter in the warm 20th century calibration period. This increased temperature sensitivity likely originates from altered fractionation processes in an overall warmer environment: higher temperatures cause higher $\delta^{18} \mathrm{O}$ in precipitation, enhanced evaporation enriches ${ }^{18} \mathrm{O}$ in soil water, and higher transpiration rates increase ${ }^{18} \mathrm{O}$ in leaf water (Raffalli-Delerce et al., 2004).

The temperature signal in $\delta^{13} \mathrm{C}$ is substantially increased during the cooler and wetter summers of the first half of the 19th century, whereas in the warmer late 20th century precipitation becomes more relevant. We hypothesize that during the less favorable thermal conditions of the early 19th century, photosynthetic rates (forced by temperature and irradiance) controlled fractionation, while during the late calibration period, stomatal conductivity (forced by soil moisture and air humidity) controlled the discrimination against ${ }^{13} \mathrm{C}$. This would also explain the stronger correlation with precipitation in the late period (discussed below).

Sunshine hours are often disregarded in calibration studies as this parameter generally correlates closely with temperature (e.g., $r_{1946-2000}=0.42$ for June-September). Nevertheless, sunshine directly affects wood density and carbon isotopes, and anatomical studies showed that a decrease in light intensity and duration results in a decline in tracheid dimension and lighter latewood (Yasue et al., 2000). Sunshine hours were here identified as the leading climatic factor controlling $\delta^{13} \mathrm{C}$ variability during the recent calibration period. The association likely arises from direct effects on photosynthetic and soil evaporation rates (Farquhar et al., 1989). Similar findings have been reported for $\delta^{13} \mathrm{C}$ in latewood cellulose from Pinus sylvestris growing in high latitude environments (McCarroll et al., 2003). Our study also reveals sunshine effects on $\delta^{18} \mathrm{O}$ particularly in the high frequency domain and during the cold season. While the cold season signal remains fairly unclear, we generally expect ${ }^{18} \mathrm{O}$ enrichment in leaf water during sunny days to mask potential source water signals at inter-annual scales.

\section{Precipitation and relative humidity}

As water availability is not a limiting factor of photosynthesis at the study site, its influence on the growth proxies appears to be restricted. We found spring precipitation to be negatively correlated with TRW, possibly by delaying snowmelt and therefore shortening the growing season (Kirdyanov et al., 2003). Adverse effects of increased cloudiness on photosynthetic activity are likely the reason for slightly negative correlations between summer 
precipitation and MXD (Yasue et al., 2000). Interestingly, relative humidity, which at this high elevation site may be considered as a proxy of overcast conditions, shows an even stronger negative connection with MXD.

$\delta^{13} \mathrm{C}$ is the only proxy that appears to be directly affected by summer precipitation through soil moisture effects on stomatal regulation (Farquhar et al., 1989; Warren et al., 2001). The moderate correlation with precipitation $(\mathrm{r} \leq-0.46)$, compared to more continental sites in the Alps reaching $\mathrm{r}=-0.75$ (Treydte et al., 2001), seems to be related to balanced soil moisture tensions buffering stomatal activity in our sampling site. Other work showed the magnitude of $\delta^{13} \mathrm{C}$ climate signals to vary along environmental gradients. Whereas oak trees growing in oceanic conditions contain weaker signals not exceeding $r=0.4$ (Raffalli-Delerce et al., 2004), Scots pine from high latitude and temperature limited environments reach correlations ranging from $r=0.58$ to 0.78 (McCarroll et al., 2003). Our results indicate that the sensitivity of $\delta^{13} \mathrm{C}$ to temperature and precipitation may not only vary in different bioclimatic belts, but also through time: As with temperature, the association between precipitation and $\delta^{13} \mathrm{C}$ changes from the early 19 th to the late 20 th century.

The relatively weak link between $\delta^{18} \mathrm{O}$ and precipitation is not fully surprising considering the good availability of soil water mitigating the trees' transpiration demand. Nevertheless, when considering higher frequency variations, the thermal signal retained in precipitation $\delta^{18} \mathrm{O}$ is much weaker, whereas the link to relative humidity (and sunshine, see above) strengthens, reaching significance. This effect seems to be a consequence of a stronger variability in leaf transpirative enrichment recorded in prevailingly wet and dry periods. The importance of summer precipitation and relative humidity on oxygen isotope variability was also reported for Abies alba, a drought-sensitive species sampled at an alpine site (Saurer et al., 2000). Winter precipitation acted as a driver of $\delta^{18} \mathrm{O}$ variability in juniper trees in semi-arid high mountain sites in northern Pakistan (Treydte et al., 2006), and in species with highly responsive stomata, such as Pinus halepensis, the link of oxygen isotope ratios to the plant's water status is even tighter (Ferrio \& Voltas, 2005).

\section{Potential for a multi-proxy approach}

In locations where seasonal temperature or water stresses are small, classical tree-ring growth proxies do not contain adequate quantitative climate information, whereas reconstructions based on multiple proxies might provide more suitable results (Raffalli-Delerce et al., 2004). In our treeline site, combining temperature sensitive proxies did not substantially improve the strength of the linear relationship that could be obtained using a single proxy. This is because MXD alone contains a rather significant and time-invariant mid summer temperature signal ( $\mathrm{r}$ $\geq 0.64$ ). Nevertheless, reconstructions integrating multiple proxies based on relatively independent physiological mechanisms likely provide more reliable estimates of past climate variability (Bräuning, 2001; Raffalli-Delerce et al., 2004). Since the physiological drivers of carbon and oxygen isotope variations differ, these proxies were shown to provide complementary estimates of climate variability (Ferrio \& Voltas, 2005).

The minor difference between multiple- and single-proxy based models suggest that common signals due to shared eco-physiological factors are limited, even if substantial co-variance among the chronologies was recorded. This conclusion is supported by the cross-correlation results between $\delta^{13} \mathrm{C}, \delta^{18} \mathrm{O}$ and MXD during the early calibration period, when these proxies share temperature as the main controlling factor. The $\delta^{18} \mathrm{O}$ and MXD chronologies also correlate significantly in the late calibration period, during which the sensitivity of oxygen isotope ratio to temperature even increased. Despite the fact that both $\delta^{13} \mathrm{C}$ and $\delta^{18} \mathrm{O}$ record environmental information via stomatal regulation (Farquhar et al., 1982), temporally consistent relationships between these stable isotope ratios are lacking. Weak associations between carbon and oxygen isotope chronologies are also reported from Pinus halepensis in semiarid to humid Mediterranean environments (Ferrio \& Voltas, 2005) and from Pinus sylvestris in northern European sites (overview in Treydte et al., 2007). Interestingly, $\delta^{13} \mathrm{C}$ and $\delta^{18} \mathrm{O}$ are more closely coupled during warmer and dryer periods, when stomatal conductance seems to be more influential, particularly after emphasizing inter-annual variability using high-pass filtered data.

\section{Conclusions}

We present the first systematic analysis of climate signals in tree-ring stable isotopes and growth proxies during distinctly cold and warm calibration periods. Our results indicate that $\delta^{13} \mathrm{C}$ and $\delta^{18} \mathrm{O}$, together with TRW and MXD, contain substantial information on inter-annual climate variations in a treeline site in the Central Alps. Temperature, sunshine hours, precipitation and relative humidity all influence various fractions of the tree-ring growth and stable isotope proxies. Yet, in this subalpine environment, overall greater correlations $(r \approx 0.6)$ are obtained with warm season temperature and sunshine data. Information on the inter-annual variability of summer precipitation is contributed by the $\delta^{13} \mathrm{C}$ data, though 
correlation coefficients are likely too low for reliable paleoclimatic reconstructions.

When evaluating the temporal consistency of climate signals, the tree-ring growth proxies showed more stable responses. In contrast, $\delta^{13} \mathrm{C}$ is more temperature sensitive in the cold calibration period and more precipitation sensitive in the warm calibration period. These results are in line with the predominant physiological process discriminating against the heavy ${ }^{13} \mathrm{C}$. The $\delta^{18} \mathrm{O}$ series mainly act as a proxy of the isotopic composition of summer rain, and therefore of local condensation temperatures. However, in the warmer 1946-2000 calibration period, higher precipitation $\delta^{18} \mathrm{O}$ and increased evapotranspiration contributed to an enhanced signal recorded in the treering cellulose. While an increasing sensitivity along environmental gradients has been described for carbon and oxygen isotope data (overview in Frank et al., 2015; Saurer et al., 2014; Treydte et al., 2007), our results clearly demonstrate that temporally varying climate signals must be taken into account when considering long isotopic chronologies for reconstruction purposes. The European Alps are certainly a key area to further investigate these relationships.

The temperature sensitivity of various tree-ring proxies allowed the development of a reconstruction based on multiple regression explaining up to $46 \%$ of the inter-annual variance of this factor. However, at our high elevation sampling site, this approach does not notably improve the temperature signal compared to using only MXD, as this proxy alone accounts for the majority of reconstructed variance. Nonetheless, the different tree-ring proxies record climate variability based on relatively independent physiological processes, and comparing these relationships will likely improve the interpretation of climate reconstructions.

\section{Acknowledgements}

A.C. acknowledges support by the Swiss National Science Foundation (MHV fellowship PMPD 106173/1). We thank Daniel Nievergelt for help with sample preparation, Carlo Casty for providing precipitation data, and Brigitta Ammann, Ulf Büntgen and David Frank for discussion.

\section{References}

Anderson WT, Bernasconi SM, McKenzie JA \& Saurer M (1998) Oxygen and carbon isotopic record of climatic variability in tree ring cellulose ( $P i$ cea abies): an example from central Switzerland (1913-1995). Journal of Geophysical Research 103: 31625-31631.
Antonova GF \& Stasova VV (1997) Effects of environmental factors on wood formation in larch (Larix sibirica Ldb.) stems. Trees 11: 462-468.

Birks HJB (1995) Quantitative palaeoenvironmental reconstructions: Statistical modeling of quaternary science data. Technical guide 5 (ed. by D Maddy \& JS Brew) Quaternary Research Association, Cambridge, UK, pp. 161-254.

Böhm R, Auer I, Brunetti M, Maugeri M, Nanni T \& Schöner W (2001) Regional temperature variability in the European Alps 1760-1998 from homogenized instrumental time series. International Journal of Climatology 21: 1779-1801.

Böhm R, Jones PD, Hiebl J, Frank D, Brunetti M \& Maugeri M (2010) The early instrumental warm-bias: A solution for long central European temperature series 1760-2007. Climatic Change 101: 41-67.

Bräuning A (2001) Combined view of various tree ring parameters from different forest habitats in Tibet for the reconstruction of seasonal aspects of Asian Monsoon variability. The Palaeobotanist 50: 1-12.

Brenninkmeijer CAM (1983) Deuterium, oxygen-18 and carbon-13 in tree rings and peat deposition in relation to climate. $\mathrm{PhD}$ thesis, University of Groningen, Netherlands.

Briffa KR, Schweingruber FH, Jones PD, Osborn TJ, Shiyatov SG \& Vaganov EA (1998) Reduced sensitivity of recent tree-growth to temperature at high northern latitudes. Nature 391: 678-682.

Büntgen U, Frank DC, Nievergelt D \& Esper J (2006) Summer temperature variations in the European Alps, A.D. 755-2004. Journal of Climate 19: 5606-5623.

Büntgen U, Myglan VS, Charpentier Ljungqvist F, McCormick M, Di Cosmo N, Sigl M, Jungclaus J, Wagnr S, Krusic PJ, Esper J, Kaplan JO, de Vaan MAC, Luterbacher J, Wacker L, Tegel W \& Kirdyanov AV (2016) Cooling and societal change during the Late Antique Little Ice Age from 536 to around $660 \mathrm{AD}$. Nature Geoscience 9: 231-236.

Carrer M, Brunetti M \& Castagneri D (2016) The imprint of extreme climate events in century-long time series of wood anatomical traits in high-elevation conifers. Frontiers in Plant Science 7: 683. doi:10.3389/fpls.2016.00683.

Casty C, Wanner H, Luterbacher J, Esper J \& Böhm $\mathrm{R}$ (2005) Temperature and precipitation variability in the European Alps since 1500. International Journal of Climatology 25: 1855-1880.

Cook ER \& Peters K (1997) Calculating unbiased tree-ring indices for the stud of climatic and environmental change. The Holocene 7: 361-370.

Cook ER, Buckley BM, D'Arrigo RD \& Peterson MJ (2000) Warm-season temperatures since 1600 $\mathrm{BC}$ reconstructed from Tasmanian tree rings and 
their relationship to large-scale sea surface temperature anomalies. Climate Dynamics 16: 79-91.

Cook ER, Seager R, Kushnir Y, Briffa KR, Büntgen U, Frank D, Krusic PJ, Tegel W, van der Schrier G, Andreu-Hayles L, Baillie M, Baittinger, Bleicher N, Bonde D, Brown D, Carrer M, Cooper R, Cufar K, Dittmar C, Esper J, Griggs C, Gunnarson B, Günther B, Gutierrez E, Haneca K, Helama S, Herzig F, Heussner KU, Hofmann J, Janda P, Kontic R, Köse N, Kyncl T, Levanic T, Linderholm H, Manning S, Melvin TM, Miles D, Neuwirth B, Nicolussi K, Nola P, Panayotov M, Popa L, Rothe A, Seftigen K, Seim A, Svarva H, Svoboda M, Thum T, Timonen M, Touchan R, Trotsiuk, Trouet V, Walder F, Ważny T, Wilson R \& Zang C (2015) Old world megadroughts and pluvials during the Common Era. Science Advances 1. doi:10.1126/ sciadv.1500561.

Crawley MJ (1993) GLIM for ecologists. Blackwell Scientific Publications, Oxford, UK.

D'Arrigo R, Wilson R \& Jacoby G (2006) On the longterm context for late twentieth century warming. Journal of Geophysical Research 111: D03103, doi:10.1029/2005JD006352.

Davi NK, D'Arrigo RD, Jacoby GC, Cook ER, Anchukaitis KJ, Nachin B, Rao MP \& Leland C (2015) A long-term context (931-2005 C.E.) for rapid warming over Central Asia. Quaternary Science Reviews 121: 89-97.

Dongmann GHW, Nürnberg HW, Förstel H \& Wagener $\mathrm{K}$ (1974) On the enrichment of the $\mathrm{H}_{2}{ }^{18} \mathrm{O}$ in the leaves of transpiring plants. Radiation and Environmental Biophysics 11: 41-52.

Esper J, Cook ER \& Schweingruber FH (2002) Low-frequency signals in long tree-ring chronologies for reconstructing past temperature variability. Science 295: 2250-2253.

Esper J, Frank DC, Büntgen U, Verstege A, Luterbacher J \& Xoplaki E (2007) Long-term drought severity variations in Morocco. Geophysical Research Letters 34: L17702. doi:10.1029/2007GL030844.

Esper J, Frank DC, Battipaglia G, Büntgen U, Holert C, Treydte K, Siegwolf R \& Saurer M (2010) Low-frequency noise in ${ }^{13} \mathrm{C}$ and ${ }^{18} \mathrm{O}$ tree ring data: A case study of Pinus uncinata in the Spanish Pyrenees. Global Biogeochemical Cycles 24, doi:10.1029/2010GB0037772.

Esper J, Frank DC, Timonen M, Zorita E, Wilson RJS, Luterbacher J, Holzkämper S, Fischer N, Wagner S, Nievergelt D, Verstege A \& Büntgen U (2012) Orbital forcing of tree-ring data. Nature Climate Change 2: 862-866.

Esper J, Schneider L, Krusic PJ, Luterbacher J, Büntgen U, Timonen M, Sirocko F \& Zorita E (2013) European summer temperature response to annually dated volcanic eruptions over the past nine centuries. Bulletin of Volcanology 75: 736. doi:10.1007/s00445-013-0736-z.

Esper J, Konter O, Krusic P, Saurer M, Holzkämper S \& Büntgen U (2015a) Long-term summer temperature variations in the Pyrenees from detrended stable carbon isotopes. Geochronometria 42: 53-59.

Esper J, Schneider L, Smerdon J, Schöne B \& Büntgen U (2015b) Signals and memory in tree-ring width and density data. Dendrochronologia 35: 62-70.

Farquhar GD, O'Leary MH \& Berry JA (1982) On the relationship between carbon isotope discrimination and the intercellular carbon dioxide concentration in leaves. Australian Journal of Plant Physiology 9: 121-137.

Farquhar GD, Ehleringer JR \& Hubick KT (1989) Carbon isotope discrimination and photosynthesis. Annual Review of Plant Physiology and Plant Molecular Biology 40: 503-537.

Ferrio JP \& Voltas J (2005) Carbon and oxygen isotope ratios in wood constituents of Pinus halepensis as indicators of precipitation, temperature and vapour pressure deficit. Tellus B-Chemical and Physical Meteorology 57: 164-173.

Fonti P \& Babushkina E (2016) Tracheid anatomical responses to climate in a forest-steppe in Southern Siberia. Dendrochronologia 39: 32-41.

Fox J (2002) An R and S-Plus companion to applied regression. Sage Publications, Thousand Oaks, California, USA.

Francey RJ, Allison CE, Etheridge DM, Trudinger CM, Enting IG, Leuenberger M, Langenfelds RL, Michel E \& Steele LP (1999) A 1000-year high precision record of $\delta^{13} \mathrm{C}$ in atmospheric $\mathrm{CO}_{2}$. Tellus B- Chemical and Physical Meteorology 51: 170-193.

Frank D \& Esper J (2005) Characterization and climate response patterns of a high-elevation, multi-species tree-ring network in the European Alps. Dendrochronologia 22: 107-121.

Frank D, Esper J, Zorita E \& Wilson RJS (2010) A noodle, hockey stick, and spaghetti plate: a perspective on high-resolution paleoclimatology. Wiley Interdisciplinary Reviews Climate Change 1: 507-516.

Frank DC, Poulter B, Saurer M, Esper J, Huntingford C, Helle G, Treydte K, Zimmermann NE, Schlese GH, Ahlström A, Ciais P, Friedlingstein P, Levis S, Lomas M, Sitch S, Viovy N, Andreu-Hayles L, Bednarz Z, Berninger F, Boettger T, D'Alessandro CM, Daux V, Filot M, Grabner M, Gutierrez, Haupt M, Hilasvuori E, Junger H,Kalela-Brundin M, Krapiec M, Leuenberger M, Loader NJ, Marah H, Masson-Delmotte V, Pazdur A, Pawelczyk S, Pierre M, Planells O, Pukiene R, Reynolds-Henne CE, Rinne KT, Saracino A, Sonninen E, Stievenard M, switsur VR, Szczepanek M, szychowska-Kra- 
piec E, Todaro L, Waterhouse JS \& Weigl M (2015) Water use efficiency and transpiration across European forests during the Anthropocene. Nature Climate Change 5: 579-583.

Gagen M, McCarroll D \& Edouard JL (2006) Combining ring width, density and stable carbon isotope proxies to enhance the climate signal in treerings: an example from the southern French Alps. Climatic Change 78: 363-379.

Gasser T \& Müller HG (1984) Estimating regression functions and their derivatives by the kernel method. Scandinavian Journal of Statistics 11: 171-185.

Gennaretti F, Arseneault D, Nicault A, Perreault L \& Bégin Y (2014) Volcano-induced regime shifts in millennial tree-ring chronologies from northeastern North America. Proceeding of the National Academy of Sciences of the United states of america 111: 10077-10082.

Hartl-Meier C, Zang C, Büntgen U, Esper J, Rothe A, Göttlein A, Dirnböck T \& Treydte K (2015) Uniform climate sensitivity in tree-ring stable isotopes across species and sites in a mid-latitude temperate forest. Tree Physiology 35: 4-15.

Hastie T, Tibshirani R \& Friedman JH (2001) The elements of statistical learning. Springer, New York, USA.

Helama S, Arppe L, Timonen M, Mielikäinen K \& Oinonen M (2015) Age-related trends in subfossil tree-ring $\delta^{13} \mathrm{C}$ data. Chemical Geology 416: 28-35.

Hemming DL, Switsur VR, Waterhouse JS, Heaton THE \& Carter AHC (1998) Climate variation and the stable carbon isotope composition of tree ring cellulose: an intercomparison of Quercus robur, Fagus sylvatica, and Pinus sylvestris. Tellus B-Chemical and Physical Meteorology 50: 25-33.

Holmes RL (2000) The dendrochronological program library. University of Arizona, Tucson, USA.

Jäggi M, Saurer M, Fuhrer J \& Siegwolf R (2003) Seasonality of $\delta^{18} \mathrm{O}$ in needles and wood of Picea abies. New Phytologist 158: 51-59.

Jones P, Briffa KR, Osborn TJ, Lough JM, van Ommen TD, Vinther BM, Luterbacher J, Wahl ER, Zwiers FW, Mann ME, schmidt GA, Ammann CM, Buckley BM, Cobb KM, Esper J, Goosse H, Graham N, Jansen E, Kiefer T, Kull C, Küttel M, Mosley-Thompson E, Overpeck JT, Riedwyl N, schulz M, Tudhope AW, Villalba R, Wanner H, Wolff E \& Xoplaki E (2009) High-resolution paleoclimatology of the last millennium: a review of current status and future prospects. The Holocene 19: 3-49.

Kirdyanov A, Hughes M, Vaganov E, Schweingruber FH \& Silkin P (2003) The importance of early summer temperature and date of snow melt for tree growth in the Siberian Subarctic. Trees 17: $61-69$.
Kirdyanov AV, Treydte KS, Nikolaev A, Helle G \& Schleser GH (2008) Climate signals in tree-ring width, density and $\delta^{13} \mathrm{C}$ from larches in Eastern Siberia (Russia). Chemical Geology 252: 31-41.

Konter O, Holzkämper S, Helle G, Büntgen U, Saurer M \& Esper J (2014) Climate sensitivity and parameter coherency in annually resolved $\delta^{13} \mathrm{C}$ and $\delta^{18} \mathrm{O}$ from Pinus uncinata tree-ring data in the Spanish Pyrenees. Chemical Geology 377: 12-19.

Kress A, Saurer M, Siegwolf RTW, Frank DC, Esper J \& Bugmann H (2010) A 350 year drought reconstruction from Alpine tree-ring stable isotopes. Global Biogeochemical Cycles 24: GB2011. doi:10.1029/2009GB003613.

Leavitt SW \& Long A (1984) Sampling strategy for stable isotope analysis in tree rings. Nature 311 : 145-147.

Leavitt SW (2010) Tree-ring C-H-O isotope variability and sampling. Science of the Total Environment 408: 5244-5253.

Luterbacher J, Dietrich D, Xoplaki E, Grosjean M \& Wanner H (2004) European seasonal and annual temperature variability, trends and extremes since 1500. Science 303: 1499-1503.

Luterbacher J, Werner JP, Smerdon JE, Fernandez-Donado L, Gonzalez-Rouco FJ, Barropedro $\mathrm{D}$, Ljungqvist $\mathrm{FC}$, Büntgen $\mathrm{U}$, Zorita E, Wagner S, Esper J, McCarroll D, Toreti A, Frank D, Jungclaus $\mathrm{JH}$, Barriendos $\mathrm{M}$, Bertolin $\mathrm{C}$, Bothe O, Brazdil R, Camuffo D, Dobrovolny P, Gagen M, Garcia-Bustamante E, Ge Q, Gomez-Navarro JJ, Guiot J, Hao Z, Hegerl GC, Holmgren K, Klimenko VV, Martin-Chivelet J, Pfister C, Roberts N, Schindler A, Schurer A, Solomina O, von Gunten L, Wahl E, Wanner H, Wetter O, Xoplaki E, Yuan N, Zanchettin D, Zhang H \& Zerefos C (2016) European summer temperatures since Roman times. Environmental Research Letters 11: 024001. doi:10.1088/1748-9326/11/2/024001.

Masson-Delmotte V, Raffalli-Delerce G, Danis PA, Yiou P, Stievenard M, Guibal F, Mestres O, Bernard V, Goosse H, Hoffmann G \& Jouzel J (2005) Changes in European precipitation seasonality and in drought frequencies revealed by a four-century-long tree-ring isotopic record from Brittany, western France. Climate Dynamics 24: 57-69.

McCarroll D \& Pawellek F (2001) Stable carbon isotope ratios of Pinus sylvestris from northern Finland and the potential for extracting a climate signal from long Fennoscandian chronologies. The Holocene 11: 517-526.

McCarroll D, Jalkanen R, Hicks S, Tuovinen M, Gagen M, Pawellek F, Eckstein D, Schwitt U, Autio J \& Heikkinen O (2003) Multiproxy dendroclimatology: a pilot study in northern Finland. The Holocene 16: 829-838. 
McCarroll D \& Loader N (2004) Stable isotopes in tree rings. Quaternary Science Reviews 23: 771801.

Moser L, Fonti P, Büntgen U, Esper J, Luterbacher J, Franzen J \& Frank D (2010) Timing and duration of European larch growing season along an altitudinal gradients in the Swiss Alps. Tree Physiology 30: 225-233.

Myglan VS, Zharnikova OA, Malysheva NV, Gerasimova OV, Vaganov EA \& Sidorov OV (2012) Constructing the tree-ring chronology and reconstructing summertime air temperatures in southern Altai for the last 1500 years. Geography and Natural Resources 33: 200-207.

Raffalli-Delerce G, Masson-Delmotte V, Dupouey JL, Stievenard M, Breda N \& Moisselin JM (2004) Reconstruction of summer droughts using treering cellulose isotopes: a calibration study with living oaks from Brittany (western France). Tellus B-Chemical and Physical Meteorology 56: 160174.

R Core Team (2014) A language and environment for statistical computing. R Foundation for Statistical Computing, Vienna, Austria.

Rebetez M, Saurer M \& Cherubini P (2003) To what extent can oxygen isotopes in tree rings and precipitation be used to reconstruct past atmospheric temperature? A case study. Climatic Change 61: 237-248.

Rinn F (2003) TSAP-Win: time series analysis and presentation for dendrochronology and related applications. Frank Rinn, Heidelberg, Germany.

Saurer M, Maurer S, Matyssek R, Landolt W, Günthardt-Goerg MS \& Siegenthaler U (1995) The influence of ozone nutrition on $\delta^{13} \mathrm{C}$ in Betula pendula. Oecologia 103: 397-406.

Saurer M, Borella S \& Leuenberger M (1997) $\delta^{18} \mathrm{O}$ of tree-rings of beech (Fagus silvatica) as a record of $\delta^{18} \mathrm{O}$ of the growing season precipitation. Tellus B-Chemical and Physical Meteorology 49: 80-92.

Saurer M, Cherubini P \& Siegwolf R (2000) Oxygen isotopes in tree rings of Abies alba: the climate significance of interdecadal variations. Journal of Geophysical Research 105: 12461-12470.

Saurer M, Spahni R, Frank DC, Joos F, Leuenberger M, Loader NJ, McCaroll D, Gagen M, Poulter B, Siegwolf RTW, Andru-Hayles L, Boettger T, Dorado Linan I, Fairchild IJ, Friedrich M, Gutierrez E, Haupt M, Hilasvuori E, Heinrich I, Helle G, Grudd H, Jalkanen R, Levanic T, Linderholm HW, Robertson I, Sonninen E, Treydte K, Waterhouse JS, Woodley EJ, Wynn PM \& Young GHF (2014) Spatial variability and temporal trends in water-use efficiency of European forests. Global Change Biology 20: 3700-3712.

Schneider L, Smerdon J, Büntgen U, Wilson R, Myglan VS, Kirdyanov AV \& Esper J (2015) Re- vising midlatitude summer temperatures back to AD 600 based on a wood density network. Geophysical Research Letters 42: 4556-4562. doi:10.1002/2015GL063956.

Schweingruber FH, Fritts HC, Bräker OU, Drew LG \& Schär E (1978) The X-ray technique as applied to dendroclimatology. Tree-Ring Bulletin 38: 6191.

ter Braak CJF \& Smilauer P (2002) CANOCO reference manual and CanoDraw for Windows user's guide: software for canonical community ordination (version 4.5). Microcomputer Power, Ithaca, USA.

Tranquillini W (1979) Physiological ecology of the alpine timberline. Springer, Berlin, Germany.

Trenberth KE (1984) Some effects of finite sample size and persistence on meteorological statistics. Part I: Autocorrelations. Monthly Weather Reviews 112: 2359-2368.

Treydte KS, Schleser GH, Schweingruber FH \& Winiger $M$ (2001) The climatic significance of $\delta^{13} \mathrm{C}$ in subalpine spruces (Lötschental, Swiss Alps). A case study with respect to altitude, exposure and soil moisture. Tellus B: Chemical and Physical Meteorology 53: 593-611.

Treydte KS, Schleser GH, Helle G, Frank DC, Winiger M, Haug GH \& Esper J (2006) The twentieth century was the wettest period in Northern Pakistan over the past millennium. Nature 440: 1179-1182.

Treydte KS, Frank D, Esper J, Andreu L, Bednarz Z, Berninger F, Boettger T, D'Allesandro CM, Etien N, Filot M, Grabner M, Guillemin MT, Gutierrez E, Haupt M, Helle G, Hilasvuori E, Jungner H, Kalela-Brundin M, Krapiec M, Leuenberger M, Loader NJ, Masson-Delmotte V, Pazdur A, Pawelczyk S, Pierre M, Planells O, Pukiene R, Reynolds-Henne CE, Rinne KT, Saracino A, Saurer M, Sonninen E, Stievenard M,Switsur VR, Szczepanek M, Szychowska-Krapiec E, Todaro L, Waterhouse JS, Weigl M \& Schleser GH (2007) Signal strength and climate calibration of a European tree-ring isotope network. Geophysical Research Letters 34. doi:10.1029/2007GL031106.

Treydte KS, Frank DC, Saurer M, Helle G, Schleser $\mathrm{G} \&$ Esper J (2009) Impact of climate and $\mathrm{CO}_{2}$ on a millennium-long tree-ring carbon isotope record. Geochimica et Cosmochimica Acta 73: 4635-4647.

van den Wollenberg AL (1977) Redundancy analysis an alternative for canonical correlation analysis. Psychometrika 42: 207-219.

Warren CR, McGrath JF \& Adams MA (2001) Water availability and carbon isotope discrimination in conifers. Oecologia 127: 476-486.

Wigley TML, Briffa KR \& Jones PD (1984) On the average value of correlated time series, with appli- 
cations in dendroclimatology and hydrometeorology. Journal of Climate and Applied Meteorology 23: 201-213.

Wilson RJS, Anchukaitis K, Briffa KR, Büntgen U, Cook E, D'Arrigo R, Davi N, Esper J, Frank D, Gunnarson B, Hegerl G, Helama S, Klesse S, Krusic PJ, Linderholm HW, Myglano V, Osborn TJ, Rydval M, Schneider L, schurer A, Wiles G, Zhang P \& Zorita E (2016) Last millennium Northern
Hemisphere summer temperatures from tree rings. Part I: the long term context. Quaternary Science Review 134: 1-18.

Yasue K, Funada R, Kobayashi O \& Ohtani J (2000) The effects of tracheid dimensions on variations in maximum density of Picea glehnii and relationships to climatic factors. Trees - Structure and Function 14: 223-229. 